\title{
Indigenous Law and the Common Law
}

Kent McNeil

Osgoode Hall Law School of York University, kmcneil@osgoode.yorku.ca

Follow this and additional works at: https://digitalcommons.osgoode.yorku.ca/scholarly_works

Part of the Indian and Aboriginal Law Commons

\section{Repository Citation}

McNeil, Kent, "Indigenous Law and the Common Law" (2021). Articles \& Book Chapters. 2829.

https://digitalcommons.osgoode.yorku.ca/scholarly_works/2829

This Article is brought to you for free and open access by the Faculty Scholarship at Osgoode Digital Commons. It has been accepted for inclusion in Articles \& Book Chapters by an authorized administrator of Osgoode Digital Commons. 


\section{Indigenous Law and the Common Law}

(C) Kent McNeil,* Osgoode Hall Law School, 15 March 2021

The extent to which Indigenous law is part of Canadian law along with the common law and civil law has become a major issue over the past two decades. ${ }^{1}$ Judges have been reluctantly wading into the matter, expressing somewhat inconsistent opinions. For example, in Coastal GasLink Pipeline Ltd. v. Huson, ${ }^{2}$ Justice Church of the BC Supreme Court stated:

As a general rule, Indigenous customary laws do not become an effectual part of Canadian common law or Canadian domestic law until there is some means or process by which the Indigenous customary law is recognized as being part of Canadian domestic law, either through incorporation into treaties, court declarations, such as Aboriginal title or rights jurisprudence, or statutory provision.... Indigenous laws may, however, be admissible as fact evidence of the Indigenous legal perspective, where there is admissible evidence of such Indigenous customary laws. ${ }^{3}$

On the other hand, in Pastion v. Dene Tha' First Nation, ${ }^{4}$ Federal Court Justice Grammond stated:

Indigenous legal traditions are among Canada's legal traditions. They form part of the law of the land. Chief Justice McLachlin of the Supreme Court of Canada wrote, more than fifteen years ago, that 'aboriginal interests and customary laws were presumed to survive the assertion of sovereignty. ${ }^{5}$

He went on to point out that, ever since the famous case of Connolly v. Woolrich ${ }^{6}$ in 1867, the year Canada became a nation, "Canadian courts have recognized the existence of Indigenous legal traditions and have given effect to situations created by Indigenous law, particularly in matters involving family relationships."7

\footnotetext{
* Thanks to Frances Abele, John Borrows, Karen Drake, Brian Slattery, and Kerry Wilkins for their very helpful feedback on a draft.

${ }^{1}$ E.g. see Val Napoleon, “Thinking About Indigenous Legal Orders,” Research Paper for the National Centre for First Nations Governance (18 June 2007), online: http://www.fngovernance.org/ncfng_research/val_napoleon.pdf; Law Commission of Canada, ed., Indigenous Legal Traditions (Vancouver: UBC Press 2007); John Borrows, Canada's Indigenous Constitution (Toronto: University of Toronto Press, 2010); Indigenous Law and Legal Pluralism, Special Issue, (2016) 61:4 McGill Law Journal; Hadley Friedland, The Wetiko Legal Principles: Cree and Anishinabek Responses to Violence and Victimization (Toronto: University of Toronto Press, 2018); Alan Hanna, "Spaces for Sharing: Searching for Indigenous Law on the Canadian Legal Landscape" (2018) 51:1 UBC Law Review 105.

22019 BCSC 2264 (CanLII) [Huson].

${ }^{3}$ Ibid. at paras. 127, 129, citing Alderville First Nation v. Canada, 2014 FC 747 at para. 40.

${ }^{4} 2018$ FC 648 (CanLII), [2018] 4 FCR 467 (Pastion), quoting Mitchell v. MRN, 2001 SCC 33, [2001] 1 SCR 911, at para. 10.

${ }^{5}$ Pastion, supra note 4 at para. 8. See also Whalen v. Fort McMurray No. 468 First Nation, 2019 FC 732 (CanLII), [2019] 4 FCR 217.

${ }^{6}$ (1867) 11 LCJ 197, 17 RJRQ 75 (Que SC), aff'd (1869) 17 RJRQ 266, 1 CNLC 151 (Que QB).

${ }^{7}$ Pastion, supra note 4 at para. 8.
} 
While most of the judicial attention regarding Indigenous law has been in relation to family matters, ${ }^{8}$ courts have acknowledged the relevance of Indigenous law in other contexts as well. For example, as far back as the early 1990s the Federal Court acknowledged that Indian Act bands that chose their band councillors "according to the custom of the band," 9 the validity of which is acknowledged by section 2(1) of the Act, are acting in accordance with Indigenous law that has effect in Canadian law. ${ }^{10}$

Another prominent example of the application of Indigenous law occurred in Tsilhqot'in Nation $v$. British Columbia, the first Canadian case in which the Supreme Court of Canada issued a declaration of Aboriginal title. One issue at trial was whether Aboriginal title and rights are vested in the Tsilhqot'in Nation as a whole or in individual Indian Act bands. In other words, who are the proper title and rights holders? ${ }^{11}$ On this issue, Justice Vickers concluded that

... the proper rights holder, whether for Aboriginal title or Aboriginal rights, is the community of Tsilhqot'in people. Tsilhqot'in people were the historic community of people sharing language, customs, traditions, historical experience, territory and resources at the time of first contact [with Europeans] and at sovereignty assertion [by the Crown]. ${ }^{12}$

Importantly, while in Tsilhqot'in society individual bands are regarded as "the caretakers of the lands" under their authority, "the caretakers have no more rights to the land or the resources than any other Tsilhqot'in person." 13 Vickers J.'s use of the term "rights” here is significant because he was referring to the situation under Tsilhqot'in customs and traditions, both before and after European contact and Crown assertion of sovereignty. In other words, those customs and traditions contained laws that gave rise to rights. The existence of these rights that every Tsilhqot'in person had (and has) throughout Tsilhqot'in territory revealed in turn that title had to be vested in the whole nation. These conclusions were based on evidence of the customs and traditions, including Indigenous law, of the Tsilhqot'in people. Justice Vickers confirmed the existence of Tsilhqot'in law by stating: “Tsilhqot'in people were a rule ordered society. Various Tsilhqot'in elders testified about dechen ts' edilhtan (the laws of our ancestors). Chief Ervin Charleyboy testified that there are laws against taking the property of others, and against creating a disturbance in a community."14

\footnotetext{
${ }^{8}$ See Norman Zlotkin, “Judicial Recognition of Aboriginal Customary Law in Canada: Selected Marriage and Adoption Cases” [1984] 4 Canadian Native Law Reporter 1; Sébastien Grammond, Terms of Co-Existence: Indigenous Peoples and Canadian Law (Toronto: Carswell, 2013), 374-85.

${ }^{9}$ Indian Act, RSC 1985, c. I-5, s. 2(1).

${ }^{10}$ See Baptiste v. Goodstoney Indian Band [1991] 1 CNLR 34; Jock v. Canada [1991] 2 FC 355; Sparvier v. Cowessess Indian Band No. 73 [1993] 3 FC 142, [1993] 3 FC 175; Corbiere v. Canada (Indian and Northern Affairs) [1974] 1 FC 394 at 405; Gamblin v. Norway House Cree Nation Band Council, 2012 FC 1536 at para. 34; Canadian Pacific Ltd v. Matsqui Indian Band, 1999 CanLII 9362 (FCA), [2000] 1 FC 325 (FCA) at para. 29; Pastion, supra note 4 at paras. $7-14$.

${ }^{11}$ See Kent McNeil, “Aboriginal Rights and Indigenous Governance: Identifying the Holders of Rights and Authority” (2020) 57:1 Osgoode Hall Law Journal 127-72, especially 136-41. Online: https://digitalcommons.osgoode.yorku.ca/ohlj/vol57/iss1/4

12 Tsilhqot'in Nation v. British Columbia, 2007 BCSC 1700 at para. 470.

${ }^{13}$ Ibid. at para. 468.

${ }^{14}$ Ibid. at para. 431.
} 
Justice Vickers' holding that title is vested in the entire Tsilhqot'in Nation was challenged by the province of British Columbia upon appeal to the BC Court of Appeal. Justice Groberman, writing the unanimous decision, rejected the province's argument and affirmed Vickers J.'s ruling on this point. Like Justice Vickers, he found that "the evidence clearly established that the holders of Aboriginal rights within the Claim Area have traditionally defined themselves as being the collective of all Tsilhqot'in people. The Tsilhqot'in Nation, therefore, is the proper rights holder." ${ }^{15}$ Commenting on the arguments presented by British Columbia, Justice Groberman observed:

In my view, the position taken by British Columbia does not take adequate account of the Aboriginal perspective with respect to this matter. I agree with the trial judge's conclusion that the definition of the proper rights holder is a matter to be determined primarily from the viewpoint of the Aboriginal collective itself. ${ }^{16}$

As revealed in Justice Vickers' judgment, the Aboriginal perspective and viewpoint on this matter are to be found in Tsilhqot'in law.

This issue of the proper holder of Tsilhqot'in rights and title was not raised or argued in the Supreme Court of Canada. ${ }^{17}$ The declaration of the Tsilhqot'in's Aboriginal title by the Court therefore affirmed the opinions of the lower courts that the nation as a whole is the proper rights holder. ${ }^{18}$ As we have seen, those opinions were based on Tsilhqot'in law contained in Tsilhqot'in customs and traditions.

What are the implications of this case law for Justice Church's statement in Huson that, "[a]s a general rule, Indigenous customary laws do not become an effectual part of Canadian common law or Canadian domestic law until there is some means or process by which the Indigenous customary law is recognized as being part of Canadian domestic law, either through incorporation into treaties, court declarations, such as Aboriginal title or rights jurisprudence, or statutory provision"? ${ }^{19}$ Her position seems to be that Indigenous law does not exist as a matter of law until it is acknowledged as such by a treaty, statute, or court decision. This extreme positivist attitude is at odds with the common law. The rules of the common law do not suddenly come into existence because a legislature or court acknowledges them. ${ }^{20}$ Often, lawyers follow established practice that they regard as legally binding without legislative or judicial affirmation. ${ }^{21}$ Only when

\footnotetext{
${ }^{15}$ Tsilhqot'in Nation v. British Columbia, 2012 BCCA 285 at para. 150.

${ }^{16} \mathrm{Ibid}$. at para 149.

${ }^{17}$ The issue was not mentioned in the province of BC's factum submitted to the Supreme Court. See Tsilhqot'in Nation v. British Columbia, 2014 SCC 44 (Factum of the Respondents), online: SCC <scc-csc.ca/WebDocumentsDocumentsWeb/34986/FM020_Respondents_Her-Majesty-the-Queen-et-al.pdf $>$. On the contrary, the province apparently accepted Justice Groberman's reasoning, observing that, in his decision, "[t]he Aboriginal perspective was at the forefront of the recognition of the Tsilhqot'in as the collective that is the proper holder of Aboriginal rights": ibid. at para 151.

${ }^{18}$ Tsilhqot’in Nation v. British Columbia, 2014 SCC 44 (CanLII), [2014] 2 SCR 257.

${ }^{19}$ Supra note 2.

${ }^{20}$ See Allan Beever, “The Declaratory Theory of Law” (2013) 33 Oxford Journal of Legal Studies 421.

${ }^{21}$ See A.W.B. Simpson, “The Common Law and Legal Theory” in A.W.B. Simpson, ed., Oxford Essays in Jurisprudence, $2^{\text {nd }}$ series (Oxford: Clarendon Press, 1973), 75. Instances can be found in the law of conveyancing: e.g. extension to freeholders of the action of ejectment, originally developed to provide a remedy for wrongfully ejected leaseholders: see A.W.B. Simpson, A History of the Land Law, ${ }^{\text {nd }}$ ed. (Oxford: Clarendon Press, 1986), 144-49.
} 
disputes arise that end up in court are judicial rulings made that create binding precedents. ${ }^{22}$ But when judges decide cases they always apply the law retroactively to the time when the facts of the case before them arose. ${ }^{23}$ In other words, the judges are declaring what the law was at the time the facts arose, not at the time the judgment is handed down. They are applying what they regard as existing law. They do not do this in a vacuum. Instead, they rely on prior precedents, analogous cases, legal principles, and what might be called "the logic of the law."24

So when a Canadian court acknowledges the existence of Indigenous law, it is not suddenly creating that law or giving it legal force that it did not enjoy before. This is clear in the Tsilhqot'in Nation case. The Tsilhqot'in customs and traditions that gave rise to the rights of every Tsilhqot'in person to use land and access natural resources throughout Tsilhqot'in territory existed before the arrival of Europeans in Tsilhqot'in territory and continued after Crown assertion of sovereignty. That was demonstrated by evidence presented at trial. Justice Vickers and the BC Court of Appeal then relied on that evidence of Tsilhqot'in law to reach another legal conclusion, namely that Aboriginal title and rights were and are vested in the entire Tsilhqot'in Nation. This was all affirmed by the Supreme Court of Canada without any need to explicitly incorporate this Tsilhqot'in law into Canadian law by court declaration, as Justice Church seems to have thought is required. Indigenous law exists and is followed in Indigenous communities. It is part of Canadian law and can be applied by Canadian courts without being specifically incorporated into Canadian law by treaty, statute, or judicial decision.

However, because Canadian judges generally are not familiar with Indigenous law the way they are with the common law and civil law (in Quebec), they need evidence in order to understand and apply it. This requires testimony by experts, such as Elders and Indigenous knowledge-keepers who understand a nation's laws and are authorized to speak about them, and anthropologists and other scholars who have studied a particular nation's legal order and become familiar with it. This requirement of evidence of Indigenous law is simply a practical matter - it does not mean Indigenous law is any less part of the domestic law of Canada than the common law and civil

\footnotetext{
${ }^{22}$ This is evident from cases where English courts had acknowledged the legally-binding effect of local customs. To be enforceable in court, these customs must have been practised (not necessarily continuously) since time immemorial (theoretically, since 1189). In other words, all the court does is acknowledge the existence of a lawful custom that has been in existence and acted on for a long, long time. See Scales v. Key (1840) 11 Ad. \& El. 819; Mercer v. Denne, [1905] 2 Ch. 538 (CA); New Windsor Corporation v. Mellor [1975] 3 All ER 44 (CA); Halsbury's Laws of England, 4th ed., vol. 12(1) (London; Butterworths, 1998), paras. 601-92.

${ }^{23}$ See discussion of Donoghue v. Stevenson [1932] AC 562 (HL), in Rupert Cross and J.W. Harris, Precedent in English Law, $4^{\text {th }}$ ed. (Oxford: Clarendon Press, 1991), 31-33. See also R.H.S. Tur, "Time and the Law” (2002) 22 Oxford Journal of Legal Studies 463.

${ }^{24}$ For further discussion, see Kent McNeil, "Indigenous Rights Litigation, Legal History, and the Role of Experts” (2014) 77 Saskatchewan Law Review 173 at 195-201, also in John Borrows and Michael Coyle, eds., The Right Relationship; Reimagining the Implementation of Historical Treaties (Toronto: University of Toronto Press, 2017), 70 at 95-102.
} 
law. ${ }^{25}$ Evidence through the testimony of experts is similarly required for proof of foreign law and international law because Canadian judges are not expected to be familiar with them. ${ }^{26}$

In sum, Indigenous law exists in much the same way the common law does. It is living law grounded in Indigenous customs and traditions. It does not need to be validated by treaty, legislation, or judicial pronouncement to be part of Canadian law. But to be applied by Canadian courts, evidence of Indigenous law has to be presented through testimony by Elders, knowledgekeepers, and other experts. Indigenous law, while it may contain common features in the way European legal systems do, can vary greatly in detail from one nation to another. It is an expression of the rich diversity of Indigenous cultures.

\footnotetext{
${ }^{25}$ See R. v. Marshall; R. v. Bernard, 2005 SCC 43 (CanLII), [2005] 2 SCR 220 at para. 130, where Justices LeBel and Fish, concurring in result, quoted John Borrows with approval: "Aboriginal law should not just be received as evidence that Aboriginal peoples did something in the past on a piece of land. It is more than evidence: it is actually law. And so, there should be some way to bring to the decision-making process those laws that arise from the standards of the indigenous people before the court” (John Borrows, "Creating an Indigenous Legal Community” (2005) 50 McGill Law Journal 153 at 173).

${ }^{26}$ See Karen Drake, “Indigenous Oral Traditions in Court: Hearsay or Foreign Law?” in Karen Drake and Brenda L. Gunn, eds., Renewing Relationships: Indigenous Peoples and Canada (Saskatoon: University of Saskatchewan Native Law Centre, 2019), 281-307. On proof of foreign law, see Richard Fentiman, Foreign Law in English Courts:

Pleadings, Proof and Choice of Law (Oxford: Oxford University Press, 1998); Sidney N. Lederman, Allan W. Bryant, and Michelle K. Fuerst, The Law of Evidence in Canada, $4^{\text {th }}$ ed. (Markham, ON: LexisNexis Canada, 2014), §12.164; David M. Paciocco and Lee Stuesser, The Law of Evidence, $7^{\text {th }}$ ed. (Toronto: Irwin Law, 2015), 201.
} 